\title{
THE ROOTS OF JAPANESE LEGAL TERMINOLOGY
}

\author{
Yuki HORIE \\ Adam Mickiewicz University \\ Institute of Linguistics \\ Laboratory of Legilinguistics \\ Al. Niepodległości 4, pok. 218B \\ 61-874 Poznań, Poland \\ pupu@amu.edu.pl
}

\begin{abstract}
During the Meiji era, Japan began its modernization and the Western culture was introduced to Japan. Japan had to construct a modern society, fusing complicatedly with a model of the Japanese tradition. In the legislation field, beginning with the Constitution of the Empire of Japan, the establishment of the first unified nationwide law was attempted in this period. In particular concerning the civil code, The French Code (later German Code) was considered as the most comprehensive code, and its translation was made and edited as a Japanese Civil Code. However, translating the original concepts which had not existed in Japan was a very difficult task. They coined words preserving the original sequence of elements and as a result there is a gap between the European legal terms and the Japanese ones especially in translation. The current legal terminology was made based on such a historical background, in consequence it has become less familiar to Japanese people. I would like to consider theses problems on some examples.
\end{abstract}

\section{日本語における翻訳語としての法律用語の歴史}

\begin{abstract}
:
明治時代の文明開化に伴い、西欧の文化が日本に流入した。日本は独自の制度や文化を維 持しつつ、西欧文化を取り入れながら近代化をすすめていった。法律においても、憲法制 定を始めとし、日本で始めて国内を統一寸る法律の制定が行われた。民法においては特に フランス、のちにドイツの民法が手本とされ、これらの民法の日本語への翻訳作業が行わ れた。しかしながら、もともと日本に存在しなかった概念を翻訳することは、非常に困難 な作業であり、結果的に誤訳や意味不明瞭な造語が多く生まれた。現在の法律用語はその ような歴史的背景をもとに成り立っているため、なお多くの一般の日本人にとって意味不 明で親しみにくい言語となっている。これらの法律用語が造語された過程についていくつ か例をあげて考察したいと思う。
\end{abstract}

\section{Introduction}

Considering Japanese law from the linguistic point of view, 1868 can be said to be the starting point with the establishment of the Great Japanese Imperial Constitution of the Meiji era. In this time, Japan quickly accepted French and German law, in particular the civil code.

It was also at that time when new concepts that did not exist in Japan flowed in from Europe. There was a difficulty with the translation of legal terms because there was no conceptual basis for words such as 'civil law', 'privacy law' or even 'rights' in 


\section{Comparative Legilinguistics 4/2010}

Japanese. It was almost impossible to elaborate these new concepts from traditional words. Japanese vocabulary was poor in terminology suitable for modern times. In addition, Japanese people did not have a notion based on the rationalism and Christianity of Europe.

On this account, there were even thoughts of adopting English as an official second language in Japan. Against this thought Yukiti Fukuzawa ${ }^{13}$, a scholar of the enlightenment, insisted on casting appropriate new Japanese phrases, which in turn allowed legal scholars to succeed.

It is the terms especially made for translation in the Meiji era that concern us here; these are called 'Meiji go' (the words of Meiji). The source language was often not clear; it might be German, French or Dutch, which were very influential in the late Tokugawa period. For example, the concept of 'civil law' was adopted in Japan from the French law, but the translation '民法[Minpô]' had existed with the original Dutch word before French law was applied in Japan.

As well as civil law, most of the terms specially made for the translation of the law in this time consist of Chinese characters (Kanji). The first reason for this was that the scientific study in Japan was always performed with Japanized Chinese rather than pure Japanese, and the new thought in the Meiji era was imported with the same method. The second reason was that the abstract concepts can be expressed by compounding two or three Kanji, and it is extremely easy to make a verb or adjective from a noun, which was formed in this way. In other words, the Chinese characters possessed the ability for extremely rich coinage, and it may be said that Japanese historically has described new ideas with by means of word formation.

\section{The historical background}

The periods of modern Japanese law can be divided into three stages: from 1868 to 1879 , from 1880 to 1904 , and from 1905 until the end of World War II. The first stage was the transition period when modern laws and ordinances could not become a dominant element against the Buddhist monk system. During the second stage, which is called the revolutionary period, European countries demanded Japan to modernize, as a precondition to abolish the unequal treaties between the two countries. Japan had to construct a modern society, fusing complicatedly with a model of the Japanese tradition. During the last period the modern law was revised according to the development of the society.

\section{The transitional period}

When the Edo Syogunate was over, the Meiji government had the problem of constructing a resistance system against Western European countries. However, the situation was not suited to the modernization at that time because the opinions of the Meiji government's members were divided. Some of them supported the feudal system

\footnotetext{
13 Yukiti Fukuzawa (10 January 1835 - 3 February 1901), Japanese author, writer, teacher, translator, entrepreneur and political theorist.
} 
and others supported capitalism and so on. In addition, the national upper echelon was the royalty, the court noble, the daimyo (feudal lords) and Confucian scholars. Under the governmental bureaucracy of such non-establishment, the various laws and the ordinances were established. It can be said that it was time of chaos. Concerning the Civil Law, more than 300 feudal clans existed those days, and there was an attempt to make a unified nationwide Civil Code. The French Code was considered as the most comprehensive code, and its translation was made and edited as a Japanese Civil Code. However, the translators did not have enough documents and dictionaries to translate the legal terminology, so they coined words preserving the original sequence of elements. It goes without saying, there were many problems with these translations.

\section{The revolutionary period}

The Civil Code was drafted under the supervision of the French scholar of the law, Gustave Emile Boissonade de Fontarabi ${ }^{14}$, who was employed by the Meiji Government. This draft was promulgated on April 21, 1890 and was to be enforced on January 1, 1893. However, the project encountered fierce opposition and was never implemented. The biggest criticism was against Family Law, where the family was understood to be the rights and obligations of the individual, and the traditional Japanese legal order of '家[ie] (a family, a household)' was completely excluded. 'Ie' was the basic unit of the Japanese family, which was considered to consist of grandparents, their son, his wife and their children. At that time, the members of the 'ie' belonged to the oldest man, and they did not have the right as an individual. As a result, the 'reinspection idea' was approved in 1890, and it became the basis of the Civil Law of the Meiji era. The Japanese traditional way of thinking was based on the respect toward the master, which means here the ancestors or the Emperor, and the basis of the family is the house (Ie), which was expanded as a nation. This idea stood in contradiction to the European individual standard, which was one of the ideas of the European Civil Code. At that time, because the German Law was used during the enactment of the Japanese Constitution大日本帝国憲法[dainippon teikoku kenpô] ${ }^{15}$, the Civil Code was also influenced by the German method of pandect system. The Meiji Civil Code was finally promulgated in May 1898 and enforced on July 16, 1898. It was consisted on the five chapters: '総則[sôsoku] the General Rules', '物件[bukken] the Property Right', ‘債権 [saiken] the Credit', ‘親族[sinzoku] the Relatives' and ‘相続[sôzoku] the Succession'.

\section{The revision period}

${ }^{14}$ Gustave Emile Boissonade de Fontarabi (7 June 1825- 27 June 1910), French legal scholar, responsible for drafting the Japanese Civil Code during Meiji era.

15 大日本帝国憲去 [dainippon teikoku kenpô], more commonly known as the Imperial or Meiji Constitution, fundamental law of the Empire of Japan from 29 November 1980 till 2 May 1947. After the Second World War, it was replaced by the new constitution 日本国憲去 [Nihonkoku kenpô], which replaced the imperial system from the form of a liberal democracy. 


\section{Comparative Legilinguistics 4/2010}

This period was an age of commerce and industrial development, in which capitalism was established in Japan. Therefore, the nation was considered as one large family, and the emperor was the head of all and therefore should be respected by all nations. It was pointed out that the education of such a concept did not exist in the legal system. Thus, the concept of nationalism as equivalent to the family was discussed. As for civil law, the revision was necessary because it was considered as too individualistic. However, it was only in the family law court that concretely achieved as a revision and 'The Personnel mediation method' was enacted in 1939. Even nowadays mediation is the best way to find the solution of quarrels between people in Japan. The Japanese idea of 'harmony (和[wa])' can be seen here, and it contradicts the individualism of the Western way of thinking. The fact is that it became an obstacle for the establishment of modern Japanese law. In short, this is the Japanese tradition, ethics and morality.

\section{Examples of coined words}

I would like to give examples of the legal terms that were translated below from French and German in the Meiji era. I concerned myself primarily with legal terms from the civil law. It can be seen that there is a gap between the European legal terms and the Japanese ones especially in translation. I suppose that this is due to the difference between the European philosophy that was not understood those days by Japanese, and the Japanese tradition which was indispensable in the Japanese life.

1. 私権 $[$ siken](les droits civils $)=$ private right, 民法 $[$ minpô] $($ le droit civil $)=$ civil law

'私権 [siken]'is the term translated from French term 'droits civils'. This 'droits' is the plural form and it can be translated as the right (権[ken]) in Japanese. However, the 'droit civil' is the singular form which means '民法[minpô]' in Japanese but this singular form 'droit' is translated as 'law (法[hô, pô])' in Japanese. That means the French 'droit' has two meanings: 'right' and 'law', as do 'Recht' in German and 'prawo' in Polish. However, for many Japanese the image of the right and the law is totally different. Most of the Japanese have the image that the law is something which is enforced while a person's rights are related to freedoms.

Then what are the law and the right for Japanese? At first, let us start from the word law '法[hô]' in Japanese. The ideograph of the law was created in China approximately 3000 years ago, and its traditional form is '溏”. There is the opinion that it denotes a kind of goat used on the occasion of the judgment by God. Another opinion is that it stands for a kind of dangerous animal which was shut in the pond not to escape (because the left part, radical of the character, is called ‘さんずい[sanzui]' and it means water). From these two interpretations the meaning comes out to 'make a rule and keep it'.

Now, let us analyze the right in Japanese '権利[kenri]'. ‘権利' can be divided into two parts '権[ken]' and '利[ri]' according to the ideographs. The original meaning of the character '権' is a 'weight to hang' and later it was interpreted as 'weight, power and 
strength'. On the other hand, the character '利' originally meant 'to cut rice with a sword' and later the meaning of this character became 'to make a bet'. The combination of '権' and '利' is originally a Chinese word, and the current meaning as a right was made in Meiji era in Japan. Before the Meiji era, "right” was translated as '道理[dôri] (reason)', '理[ri] (the law of the nature)' or '公儀[kôgi] (public morality)'. For the first time in 1868, the word '権利'appeared as the translation of the 'right (droits)' in the EnglishJapanese dictionary '和英語林集成[waeigo rinsyûsei]'. The ‘権利' was considered as correctness in morality as well as in legal matters. This translation '権利' was probably imported from China, because in the British Sinter Chinese-English dictionary (1866), the 民之権min-no-ken was translated as the 'Right of the citizen'. However, the character '権' has the meaning not only the 'correctness' but also the 'power', which has existed for a long time. According to the dictionary '和英語林集成”, the “権” means 'power, authority and influence' (Yanabu 2006). Correctness and the power have often two opposite images, and it was difficult for Japanese people to understand the word '権利' at that time. It may be said that the original meaning of 'droits' was slowly understood in the course of adopting the thought of the modern times in Japan.

As stated before, the translation of the term 'droit civil' is '民法[minpô]' in Japanese, and 'droits civils' is '私権[siken]'. In other words, the term' civil' is translated once '民[min] (public)', and '私[si] (“I” or “private”)'. ‘私' has a similarity to individuality (個人kojin), while '民' reminds us of cooperation or solidarity. Why was the word 'civil' translated with two such contrary words in Japanese?

I will now analyze the meaning of the word 'civil'. The most important meaning of 'civil' is 'cité (city)'. From this meaning, it can be deduced the meaning as each individual who lives in this city, the cooperation of the people of the city, the inside of the city against the outside, the political power who defends the city, etc. These variable meanings were translated in Japanese once '民( public)', and once '私(I or private)'.

2. 人 [hito] (une personne) $=$ person, 物 $[$ butu $]($ une chose $)=$ thing

The title of the first chapter of the first volume of the Japanese civil law is '人[hito] (the person)'. A question arises, who is the person? According to the civil law, the person means 'the beginning of the capability of the right'. That means '人' does not mean only a human being, but also the organization which has such capability. According to the civil law, the former is called '自然人[sizenzin] (natural person)' and the latter is called '法人[hôzin] (juristic person, legal person)'. Concerning the term '法人' , it seems to be suitable as a term of translation in English 'legal person', but on the other hand, “自然人' is a word with the sense of incongruity for a general Japanese. Because '自然' means trees, flowers, mountains or the sea, and this is worshiped as the thing which God dwells in the Japanese religion Shinto. Therefore, it is the word that nature (God) and the human being put together to become a single word, and needless to say, it is used only as a legal term. 


\section{Comparative Legilinguistics 4/2010}

'人' is the Chinese ideograph which indicates a person walking. The combination with other characters gives the possibility to render the meaning more precisely. For example, '個人[kozin]' means 'individual'; '人類[zinrui]' means 'mankind'. There is another term which also has the meaning of 'person'. It is the pure Japanese word called '者[mono]'. The original meaning of 'mono' is 'something or someone who pulls the attention' and there is no distinction with regard of this 'mono' being inanimate or animate. The expression 'ものものしい[monomonosii]' means something or someone very serious or high-sounding. That is why when it is written 'もの' in Chinese characters, there are two ways, one '物[mono, butu]' (thing) and another '者[mono]' (person).

The title of the third chapter of the first volume of the Japanese civil law contains the character '物[butu]' (thing). This is the kanji character which is usually pronounced 'mono', but in jurisprudence it is pronounced 'butu' to prevent the confusion with the homonym '者[mono]'. The pronunciation 'butu' apart from the jurisprudence carries a vulgarized meaning 'drug' or 'stolen things', but except for this case it is never pronounced as 'butu'. Usually it can be pronounced 'butu' only in the combination with another Kanji. The Chinese character '物' is composed of two parts. One is cow '牛[usi]', and another is the hieroglyph '勿'. Here the cow does not has a special meaning; on the other hand, this hieroglyph '勿' pictures fluttering cloth. The original meaning of the character was 'something which is not characteristic' or 'various things'. '物' is a term expressing the object of the right for a person, which is the subject of the right.

\section{3. 契約 $[$ keiyaku] $($ der Vertag $)=$ contract}

'The contract' is a term very well known, but it came into existence only during the Meiji era. Originally, this term was an old Chinese word used with the classic 'Wei book $^{16}$, 1700 years ago, and meant 'a decision and the promise that were performed as a ceremony.' '契[kei]' means the seal, and the '約[yaku]' the remarkable sign. It corresponds to 'der Vertag' in German law. This term has a meaning as a reflexive verb 'doing with someone peacefully', and it can be in a wide sense interpreted as 'a tie between two persons'. A contract and a tie are different notions, but it can be understood as follows: the relation between the person is formed by the personal will and in case of an unpleasant situation it can be cut off also by personal will. Like human relations, the tie can be established or dismantled. In this case, the tie and the contract exhibit some similarities. On the other hand, in Japan, the relations among persons are considered as a bond, which transcends personal will. In other words, human relations are given to people by gods without being concerned if an individual wants it and the relation with others might be psychological connection. In Germany, a lawsuit in court is aimed at clarification of human relations, but in Japan people themselves cannot change the human relations made by gods, and thus the lawsuit sometimes makes the relations worse. Here

16 The Wei Book (The Book of Wei) ( in Chinese魏書魏书, pinyin: Wèishū), classic Chinese historical writing. 
we can see the difference in the way of thinking about human relations and the law in Japan and in Europe.

4. 公序良俗 [kôzyo ryôzoku] (l'ordre public et le bonnes mœurs) = public order and morals

The word 'public order and morals' appears in article 90 in the civil law. And this is a translation of the 'l'ordre public et le bonnes mœurs' in the French Civil Code (art.6). This term can be divided into and analyzed along four parts according the Kanji: ‘公[kô] (public)', ‘序 [zyo] (order)', ‘良[ryô] (goodness)' and '俗[zoku] (manner)'.

\section{1. 公[kô, ôyake]}

'公[kô, ôyake]' is the opposite of '私[watakusi, watasi, si] (private, I)' and '公' means as a legal term 'concerning the whole nation'. It is a translation of the French term 'public' and it means 'to open to everyone'. However, the character '公' has been used in China since ancient times as the name for government officials. In Japan also the officials who served the Emperor have been called kô. Then why was the French 'public' translated as '公' which meant officials who served the Emperor? This is because the Meiji Emperor wanted to make the world be led by him, he interpreted the original meaning 'to open to everyone' as 'to concern to the whole nation which serves the Emperor. After World War II, the Emperor became the symbol of the nation, and it is actually translated as 'public'.

\section{2. 序 [zyo]}

'序 [zyo] (order)' was used in China from the $3^{\text {rd }}$ century, and its meaning was 'one's turn' or 'the order of the thing'. In modern times, this word was used as a translation of 'order' in English, 'ordre' in French or 'Ordnung' in German. But, generally, this Kanji is used in combination with other Kanji, like '秩序[tituzyo] (order) 'or '順序[zyunzyo] (one’s turn)'.

\section{3. 良[ryô,yo(i)]}

‘良[ryô,yo(i)] (an abbreviation of 善良 [zenryô] )' is a word which was used as one of the five classics of Confucianism from a long time ago. '善良' consists of two Kanji: 善 and 良. Both of them are pronounced in Japanese [yo(i)], ([zen] and [ryô] is the Chinese pronunciation), and both of them have the meaning 'goodness'. However, the 善 is the goodness based on moral values, while 良 means the quality of state.

\section{4. 俗 $[\mathrm{zoku}]$}




\section{Comparative Legilinguistics 4/2010}

'俗[zoku]' is the old Chinese word which means 'appearance'. It came to be used as an equivalent of the French 'mœur' in the Meiji era. However, usually 'zoku' means worldliness, vulgarity or laity and the mœurs (morals) is translated as 倫理[rinri].

5. 法律行為 [hôritukôi] (Rechtsgeschäft) $=$ juristic act, 意思表示 [isihyôji] $=$ declaration of the intention

法律行為[hôritukôi] is one of the important key words of Japanese civil law. This word is the translation from the German 'Rechtsgeschäft'. It is necessary to generate the effect of the law, and the declaration of the intention is the vital element of the juristic act. This Japanese terminology sounds unfamiliar to a person who has not studied law. 法律行為 consists of 法律[hôritu](law) and 行為[kôi](act).

5.1. 法律[hôritu ](law)

The following three meanings are included in the word '法律'.

(i) It is a kind of the prescriptive social norm distinguished from morality.

(ii) It has general and abstract standards.

(iii) It is one form of the law of the country enacted through the Diet in Japan.

In one word, the first is 'the regulation', the second is 'the type of method', and the third is more clearly 'the law of the nation'. The meaning of the法律行為 is the third one.

\section{2. 行為 $[k o ̂ i](a c t)$}

The Chinese word '行僞[chiń xingwei]' is written in classical Chinese 'Xun $\mathrm{Zi}^{17}$ ', and this usage has already been seen as the meaning 'do' or ' act'. However the行為 which is in the Japanese law is the translation of the German terminology 'Ereignis' and 'Verhalten'. There is a difference between 'inneres Verhalten (the internal behavior)' and 'außeres Verhalten (outward behavior)', which is called 'Handlung' in German. 'Handlung' is translated into Japanese as 準法律行為[junhôritukôi] (semijuristic act). The difference of the 法律行為and 準法律行為 is the presence of the intention. This indispensable ‘意思表示[ishihyôji](declaration of the intention)' consists of ‘意思[ishi](intention)’ and ‘表示[hyôji](declaration)'.

\section{3. 意思 [isi] (intention)}

${ }^{17}$ Xun Zi (荷子; pinyin: Xún Zǐ. a Chinese Confucian philosopher who lived during the Warring States Period and contributed to one of the Hundred Schools of Thought. Xun zi is also the title of his book. 
‘意思[isi]' means 'someone's intention or will', and there is a homonym '意志 [isi](will)' the meaning of which is very similar. More precisely, ‘意思' refers to person's feeling about something which one wants to do or not as a legal matter. On the other hand, '意志' means the positive intention that someone is going to carry out till the last even if there are difficulties and objections. Usually the latter one is used the most, but as a legal term the former one was used as a translation of the German 'Wille'. Comparing the English 'will' or the German 'Wille' and the Japanese ‘意思' and '意志(will)', we can find an interesting difference. The English 'will' can be used as a verb as well as a noun; on the other hand, the Japanese '意思' and '意志' can not be used as a verb. I suppose that this grammatical difference has to do with Japanese culture. Japanese people do not like to express their will, because the typical Japanese way of thinking is to defend partner's feelings much more than the personal will. For the Japanese the most important thing in life is '和[wa] (harmony)' with others. In such way the Japanese can keep the harmony. That is why it is not used as a verbal form as an activity.

\section{4. 表示[hyôzi] (declaration)}

'表示[[hyôzi](declaration)' is the translation of the German 'Erklärung'. This German word was interpreted into Japanese as not only '表示(declaration)' but also as ‘説明[setumei] (explanation)', ‘表明[hyômei] (declaration)', '宣告[senkoku] (sentence)' and '告白[kokuhaku] (confession)'. The various terms have different meanings according to the context.

\section{Conclusion}

The following characteristics can be given of Japanese legal terms.

1. The translations were made without the concept of or the knowledge about the European law and its history. The European law was based on the right of the individuals. The European 'Individuality' has its root in Christianity. Before God, the human being is regarded as an individual, and all the individuals are treated equally. But at that time Japanese did not have such a concept. So it was extremely difficult for Japanese to understand what it means to be a person. It can be said that a person's right for a normal Japanese life did not exist. Japanese society was based on the 'ie (family)' where the loyalty and filial piety was a priority to the individual right. However, the scholars of the Meiji era considered that Christianity is the basis of the morality of the Westerners and Western civilization, so they insisted on introducing it and let Japanese citizens understand this new thought. But the Japanese language in itself, which was necessary for the education of the nation faced problem. Japanese vocabulary was too poor and undeveloped to transmit this philosophy. The scholars became desperate to achieve Japanese independence and modernization. 


\section{Comparative Legilinguistics 4/2010}

2. When Chinese culture and characters were brought over in Japan several thousand years ago, the Japanese adopted Chinese letters into the Japanese language as a '漢語 [Kango] (Chinese words)' and supplemented the poverty of Japanese vocabulary. The scholars of the Meiji era succeeded to introduce European law in this same way by creating new Japanese words from Chinese letters. Why then did they decide to use the Chinese words? They knew that from ancient times, the Japanized Chinese words rather than pure Japanese handled the logical concept of the scientific study. Confucianism and Buddhism are adopted using Chinese words in Japan; that is why even today the study of classical Chinese characters is performed in Japanese junior and high schools. The scholars of the Meiji era took a similar method too. The second reason is because it was able to express the new thought in clear form by using the Chinese characters. In addition, it was very easy to make a verb or an adjective from the noun by adding another character (for example, to make an adjective it was enough to add '的teki', 法律hôritu law $\rightarrow$ 法律的 hôrituteki legal). The third reason was that the Chinese characters completely permeated into the Japanese language even though they are from an imported language; it was easy for Japanese people to understand. That is to say, Chinese words coined in Japanese are extremely rich in meaning. However, it may be said that it was not a good solution to express abstract meaning through Chinese characters. The translated terms succeeded to keep the image that they are difficult to understand thanks to the combination of Chinese characters, which are unfamiliar to most people. But as a result, it is hard to understand what these non-daily terms really mean. It looks like a well-made box that has nothing inside. Only the limited upper classes could understand the meaning of the words. Thus, such education came to be a right only for some elites. Actually, most Japanese think that law or philosophy is something very stiff and hard to understand. Japanese tend to avoid a trial at the court because of these reasons. The Japanese expression (‘裁判沙汰になる[saibanzata ni naru] (to become the lawsuit)’ has a negative image for a general Japanese.

3. Some of the scholars in Meiji era thought that the study of the law, philosophy, religion, and science should have been given to all Japanese citizens. This means that most of the Japanese should have received a high level of education. Therefore, they tried to improve the Japanese language making it richer and more sophisticated, so that it could support such endeavors to improve the Japanese, they had to coin new words and create the image of these words. From the early years of the Meiji era, they hardly worked on the legal terminology. But by the process of translation, there was a gap between the meaning of the Chinese character which is generally known by people and the one which is used as a legal term. The Japanese tend to understand the words with an image if it is good or bad and the legal terms were influenced by this general images. One of the best examples is a concept to'自由ziyû (be free)'. In '自由民権運動[ziyûminkenundô] (a movement for the democratic rights)' performed in the Meiji era, ‘個人の自由[kozin no ziyû] (the personal freedom)' had a negative image for most of the Japanese, because the 'freedom' got the Japanese traditional '和[wa](harmony)' out of order. It became the words to express the bad effect, bad meaning and incompatibility. Of course the reason for this misunderstanding was caused by the lack of the knowledge of original meaning. The Japanese way of thinking is completely different from the English words like 'freedom' or 'liberty'. Why did the 
Japanese accept this translation '自由[ziyû] (freedom)' negatively? The reason is because the word '自由[ziyû]' was considered in Japanese as 'selfishness (to do anything what he/she wants to do)' and they think that the 'freedom' meant the selfishness. Some scholars criticized that it was an unsuitable translation, and they tried to use other words like '自主[zishu] (independence)' or '自主の理[zishu no ri] (the law of the nature of the independence)'. However, '自由' stayed as the translation because this word was the most familiar to the people. They adopted this word, and in the history brought in a new image of this word. They created the new word '自由' which was different from the old '自由'. It can be also said that the terms specially-coined for translation are the words of a heterogeneous meaning. They have unclear meanings, which we do not understand completely. But I can say that this is the characteristic of the translated words, and maybe it should be unclear because this is what it really means for Japanese.

As a result of these coined words, after the Meiji era, Japanese became a richer language. They translated using Chinese characters and without using the original European words, and in consequence, the European legal term could be Japanized and adapted to the Japanese society.

\section{Bibliography}

Gôhara, Toyoshige. 2006. 民法総則物件編 (Minpô sôsoku bukken hen). Tokyo: TAC syuppansya.

Gôhara, Toyoshige. 2006. 民法債権編(Minpô saiken hen). Tokyo: TAC syuppansya. Halpern, Jack. 1995. New Japanese English Character Dictionary. Tokyo: Kenkûsha.

Hendry, Joy. 1997. Understanding Japanese Society. London: Routledge.

Hida, Yosihumi. 2002. 明治生まれの日本語(Meiji umare no nihongo). Tokyo: Tankôsya

Huruta, Gyô, Isii Satosi, Okabe Rôiti, HiraiKazuhiro, and Kume Teruyuki. 2001. 異文化コミュニケーションキーワード(Ibunka komyunikêsyon kîwâdo). Tokyo: Yûsenkaku sôsyo.

Huruta, Hirokiyo. 2005. 翻訳語としての日本の法律用語 (Honyakugo tositeno nihon no hôritu yôgo. Tokyo: Tyûô syuppanbu.

Kawaguti, Yosihiko. 2005. 日本近代法制史(Nihon kindai hôsêsi). Tokyo: Sinseisya.

Kenbô, Hidetosi, Kindaiti Haruhiko, Shibata Takesi, Yamada Tadao, and Kindaiti kyôsuke. 1987. 新明解 国語辞典 (Simêkai kokugo ziten). Tokyo: Sansyôdô.

Kondō, Ineko, Takano Hhumi. 1989. Progressive Japanese-English Dictionary. Tokyo: Shôgakukan.

Konisi, Tomohiti, Yasui Minoru, and Kunihiro Tetuya. 1980. Progressive EnglishJapanese Dictionary. Tokyo: Shôgakukan.

Kość, Antoni. 2001. Filozoficzne podstawy prawa japońskiego w perspektywie historycznej. Lublin: Katolicki Uniwersytet Lubelski.

Murakami, Juniti. 2005. 法の歴史(Hô no rekisi). Tokyo: Tokyo daigaku syuppankai. 
Okimori, Takuya. 1990. 日本語史 (Nihongo si). Tokyo: Ôhûsya.

Ômura, Atusi. 2007.「民法 0 。1．2．３条」く私＞が生きるルール(Minpô zero, iti, ni, san zyô. $<$ Watasi $>$ ga ikiru rûru). Tokyo: Misuzu syobô

Ôtuki, tetuo, Sasaki Yasuaki, Tada Mititarô, Nisikawa Nagao, Yamada Minoru, and Amou hitosi. 1989. クラウン仏和辞典(kuraun hutuwa jiten). Tokyo:Sanseidô.

Ozaki, Tetuo. 2005. 法律英語用語辞典(Hôritu eigo yôgo ziten). Tokyo: Ziyûkokuminsya.

Saitô, Tuyosi. 2005. 明治の言葉 (Meiji no kotoba). Tokyo: Kôdansya gakuzyutu bunko.

Sotoyama, Sigehiko. 1976. 日本語の個性 (Nihongo no kosei). Tokyo: Tokyo Tyûô kôron.

Takanasi, Noriyuki, Sinohara Hirosi, Someno Yosinobu, Mizube Yosirô, Hagiwara Tarô, Yamakawa Itiyô, and Takanasi Syun'iti. 2006. 口語六法全書 口語民法 (Kôgo roppô zensyo Kôgo minpō). Tokyo: Ziyûkokuminsya.

Yamaguti Tosio. 2002. フランス法辞典 (furansu hô ziten). Tokyo:Tokyo daigaku syuppankai.

Yanabu, Akira. 2006. 翻訳語成立事情 (Honyakugo seiritsu zijyô). Tokyo:Iwanami sinsyo

Yokoi, Hideaki. Ed. 2006. 図解による法律用語辞典 (Zukai ni yoru hôritu yôgo ziten). Tokyo: Ziyûkokuminsya.

Yokoi Hideaki. Ed. 2007. 法律用語の基礎知識 (Hôritsu yôgo no kisochishiki). Tokyo: Jiyûkokuminsha. 